\title{
KETONE-BODY UTILIZATION AND LIPID SYNTHESIS BY DEVELOPING RAT BRAIN-A COMPARISON BETWEEN IN VIVO AND IN VITRO EXPERIMENTS
}

\author{
Matthys Lopes-Cardozo and WiL. KLein \\ Laboratory of Veterinary Biochemistry, State University of Utrecht, P.B. 80177, 3508 TD Utrecht, The \\ Netherlands
}

(Received 28 June 1983; accepted 28 October 1983)

\begin{abstract}
The distribution of ketone bodies between oxidation and lipid synthesis was analysed in homogenates of developing rat brain. The capacity for lipid synthesis of homogenized or minced brain preparations was compared with rates of lipid synthesis in vivo, assessed by incorporation of ${ }^{3} \mathrm{H}$ from ${ }^{3} \mathrm{H}_{2} \mathrm{O}$ into fatty acids and cholesterol. Brain homogenates of suckling rats (but not those of adults) incorporated label from $\left[3-{ }^{14} \mathrm{C}\right]$ ketone bodies into lipids, but this process was slow as compared to ${ }^{14} \mathrm{CO}_{2}$ production $(<5 \%)$ and much slower than the total rate of ketone-body utilization $(<0.5 \%)$. Study of ${ }^{3} \mathrm{H}_{2} \mathrm{O}$ incorporation demonstrated that the rates of lipogenesis and cholesterogenesis are at least one order of magnitude higher in vivo than in vitro. Maximal rates of ${ }^{3} \mathrm{H}$ incorporation into fatty acids $(3 \mu \mathrm{mol} / \mathrm{g}$ brain.h) and into cholesterol $(0.6 \mu \mathrm{mol} / \mathrm{g}$ brain.h) were found during the third postnatal week. Adult rats still incorporated ${ }^{3} \mathrm{H}$ into brain fatty acids at an appreciable rate $(1 \mu \mathrm{mol} / \mathrm{g}$ brain. $\mathrm{h})$, whereas cholesterogenesis was very low. It is concluded that in vitro measurements of lipid synthesis severely underestimate the rates that occur in developing rat brain in vivo. The high rate of ${ }^{3} \mathrm{H}$ incorporation into lipids by developing and adult rat brain as compared to the amounts of these lipids present in the brain suggests an important contribution of endogenous lipid synthesis during brain development and an appreciable rate of fatty acid turnover during brain growth, but also in the adult brain.
\end{abstract}

Ketone bodies are important metabolic substrates for the neonatal rat throughout the suckling period which coincides with the growth spurt of the brain (reviewed in Robinson and Williamson, 1980). Studies with isolated brain preparations demonstrate that ketone bodies can partly replace glucose both as an oxidative and as a lipogenic substrate (Yeh et al., 1977; Patel and Clark, 1980; Patel and Owen, 1977; Lopes-Cardozo et al., 1980). Moreover, in young rats in vivo ketone bodies are incorporated into brain lipids, with a preference for cholesterol (Webber and Edmond, 1979; Yeh, 1980; Koper et al., 1981).

During the postnatal growth spurt of rat brain, membrane assembly is a very active process which requires an efficient supply of cholesterol and of fatty acids for the synthesis of complex lipids. Uptake from the blood (Dhopeshwarkar and Mead, 1973; Lyles et al., 1975) and synthesis in situ (Webber and Edmond, 1979; Yeh, 1980; Koper et al., 1981; Dhopeshwarkar and Subramanian, 1977; Bourre et al., 1977; Cook, 1978; Murad and Kishimoto, 1978) both contribute; however, the relative importance of these processes is still a matter of debate (Bourre, 1980; Cook, 1982; Yeh et al., 1983).
The present investigation addresses the following questions: (1) How are ketone bodies distributed between oxidative and synthetic pathways in brain preparations of developing rats? (2) How do rates of lipogenesis and cholesterogenesis observed in vitro relate to these rates in vivo? (3) Is it possible to estimate the fraction of brain lipids that is synthesized in situ during development?

\section{EXPERIMENTAL PROCEDURES}

\section{Materials}

Radiochemicals were purchased from Amersham International Ltd. (U.K.). $\left[3-{ }^{14} \mathrm{C}\right]$ Acetoacetate was prepared by hydrolysis of the ethyl-ester $\left(37^{\circ} \mathrm{C}, 1 \mathrm{~h}, 0.1 \mathrm{M} \mathrm{KOH}\right)$ and neutralization with $0.1 \mathrm{M} \mathrm{HCl}$. Enzymes, substrates and cofactors were supplied by Boehringer (Mannheim, Germany) or by Sigma (St Louis, MO, U.S.A.). Wistar rats (14-day-pregnant dams, $200-250 \mathrm{~g}$ body weight) from the Central Institute for the Breeding of Laboratory Animals (Zeist, Netherlands) were caged individually. Their litters were trimmed to 10 pups and used without discrimination of sex. The mothers were separated from their pups at day 21 and used as adult controls in developmental studies (Table 1; Figs 1, 2 and 3).

\section{Brain preparations and incubation conditions}

Whole-brain homogenates $(40 \%, w / v$, in incubation me- 
Table 1. The utilization of ketone bodies by rat-brain homogenates as a function of postnatal age

\begin{tabular}{|c|c|c|}
\hline \multirow{2}{*}{$\begin{array}{l}\text { Age } \\
\text { (days) }\end{array}$} & \multicolumn{2}{|c|}{$\begin{array}{l}\text { Ketone-body utilization } \\
(\mu \text { mol } g \text { brain } / \text { hr })\end{array}$} \\
\hline & Acetoacetate & D-3-Hydroxybutyrate \\
\hline 1 & $13.7 \pm 1.1$ & $7.4 \pm 2.1$ \\
\hline 8 & $17.6 \pm 0.4$ & $16.2 \pm 0.2$ \\
\hline 15 & $25.2 \pm 1.9$ & $19.6 \pm 0.7$ \\
\hline 28 & $31.8 \pm 0.7$ & $25.1 \pm 2.3$ \\
\hline Adult & $16.6 \pm 0.4$ & $9.5 \pm 0.4$ \\
\hline \multicolumn{3}{|c|}{$\begin{array}{l}\text { Homogenates, equivalent to } 100 \mathrm{mg} \text { tissue, were incubated with } \\
4 \mathrm{mM} \text { of either acetoacetate or } \mathrm{D}-3-\mathrm{hydroxybutyrate} \text { for } 30 \mathrm{~min} \\
\text { at } 30 \mathrm{C} \text { in a medium containing } 50 \mathrm{mM} \mathrm{KCl}, 150 \mathrm{mM} \text { sucrose, } \\
2.5 \mathrm{mM} \text { Tris-EDTA, } 10 \mathrm{mM} \mathrm{Tris} \mathrm{Cl}, 1 \mathrm{mM} \mathrm{L} \text {-matate, va- } \\
\text { linomycin }(1 \mu \mathrm{g} / \mathrm{ml}) \text { and } 5 \mathrm{mM} \mathrm{MgCl} \text {. The disappearance of the } \\
\text { ketone bodies was corrected for their mutual interconversion (cf. } \\
\text { Lopes-Cardozo and Klein, 1982). Mean } \pm \mathrm{SE} \text { for triplicate incu- } \\
\text { bations. }\end{array}$} \\
\hline
\end{tabular}

dium) were prepared with a loosely fitting, ground-glass Potter pestle operated by hand. Finely minced brain was added to the incubation flasks as a suspension $\left(40^{\circ}, w / v\right.$, incubation medium). Both preparations were added with a cell-pipette with a large orifice.

The incubation medium (high potassium KrebsHenseleit-Ringer) contained $115 \mathrm{mM} \mathrm{NaCl}, 6 \mathrm{mM} \mathrm{KCl}$, $1.2 \mathrm{mM} \mathrm{MgCl}, 1.2 \mathrm{mM} \mathrm{KH}_{2} \mathrm{PO}_{4}, 1.2 \mathrm{mM} \mathrm{K}_{2} \mathrm{SO}_{4}, 2.5 \mathrm{mM}$ $\mathrm{CaCl}_{2}$ and $25 \mathrm{mM} \mathrm{KHCO}(\mathrm{pH} 7.4)$ except in experiments described in Table 1 . Brain preparations (equivalent to $200 \mathrm{mg}$ brain per flask) were incubated in $25-\mathrm{ml}$ Erlenmeyer flasks for $1 \mathrm{~h}$ at $37^{\circ} \mathrm{C}$ under $\mathrm{O}_{2}-\mathrm{CO}_{2}(95: 5, \mathrm{v} / \mathrm{v})$ unless indicated otherwise. Final volume, $1 \mathrm{ml}$. Reactions were stopped by injection of $1 \mathrm{ml} 1 \mathrm{M} \mathrm{HClO}$ and the flasks were shaken for another 30 min to trap ${ }^{14} \mathrm{CO}_{2}$ quantitatively.

\section{Ketone-body utilization}

The utilization of ketone bodies was measured by enzymatic tests (Williamson et al., 1962: Lopes-Cardozo and Klein, 1982) in samples from neutralized perchloric extracts of in vitro incubations and zero-time controls. ${ }^{14} \mathrm{CO}_{2}$ was absorbed in an alkaline solution in a disposable center well attached to the rubber stopper (Kontes, Vineland, NJ, U.S.A.). Two-hundred $\mu$ l Hyamine ( $1 \mathrm{M}$ in methanol, Packard Instruments, Downers Grove, IL, U.S.A.) was injected into the center well $5 \mathrm{~min}$ before the end of the incubation period. After the incubation, the center wells were transferred to minivials with $3 \mathrm{ml}$ Tritosol (Pande, 1976) and the ${ }^{14} \mathrm{C}$ radioactivity was measured.

Total lipids were extracted from $\mathrm{HClO}_{4}$-washed pellets (Bligh and Dyer, 1959). Control experiments indicated that less than $1 \%$ of the labeled lipids was in the supernatant and that more than $95^{\circ}$, was recovered from the washed pellets. The distribution of label among lipid classes was measured after their separation by TLC (Koper et al., 1981). Total lipids were fractionated after alkaline hydrolysis into a non-saponifiable fraction (sterols) and a saponifiable waterinsoluble fraction (fatty acids) (Koper et al.. 1981).

\section{Tritium incorporation}

Lipogenesis in the brain in vico was measured by incorporation of ${ }^{3} \mathrm{H}$ from ${ }^{3} \mathrm{H}_{2} \mathrm{O}$, essentially as described by Stansbie $e^{\prime \prime}$ al. (1976). Briefly, ${ }^{3} \mathrm{H}_{2} \mathrm{O}$ was injected $(0.1-0.2 \mathrm{mCi} / \mathrm{g}$ body weight, i.p.). Two pups were decapitated after $1 \mathrm{~h}$ and 2 pups after $2 \mathrm{~h}$. The brain hemispheres were digested separately in alkaline. Saponitiable and nonsaponifiable lipid extracts were prepared and 3- $\beta$-hydroxysterols were isolated from the non-saponifiable fraction with digitonin (Jeske and Dietschy, 1980) with a recovery of $94 \%$. The specific activity of ${ }^{3} \mathrm{H}_{2} \mathrm{O}$ in the blood plasma was determined and used to calculate the rates of fatty acid and sterol synthesis in the brain. Ratios of 0.9 and 0.7 of ${ }^{3} \mathrm{H}_{2} \mathrm{O}$ per acetyl-group incorporated into fatty acids (Lowenstein et al., 1975) and into sterols (Andersen and Dietschy, 1979), respectively. were adopted. Control experiments showed that ${ }^{3} \mathrm{H}_{2} \mathrm{O}$ equilibrated in less than 5 min over the body fluids and into the brain. The rate of ${ }^{3} \mathrm{H}$ incorporation into fatty acids and into cholesterol was linear over a period of at least $24 \mathrm{~h}$.

\section{Other analytical procedures}

Cholesterol (Zlatkis and Zak, 1969) and total fatty acids (Metz et al., 1973) were assayed in aliquots of the nonsaponifiable and saponifiable lipid extracts, respectively.

\section{Calculation.}

The specific activity $(\mathrm{dpm} / \mathrm{nmol})$ of ${ }^{1+} \mathrm{C}$-labelled substrates added to in vitro incubations was determined by measurement of their radioactivity and by enzymatic assay of their final concentration.

All values shown are means of duplicate or triplicate measurements differing less than $10^{\circ}$, unless indicated otherwise. Results were verified in at least two independent experiments.

Incorporation of ${ }^{3} \mathrm{H}$ from ${ }^{3} \mathrm{H}_{2} \mathrm{O}$ in cico: Duplicate values (for two brain hemispheres of 1 rat), differing less than $10^{\prime \prime}{ }^{\prime}$. were averaged. No difference was observed in the rates of incorporation of $1-h$ and $2-h$ experiments. The standard deviation of the mean result of 4 rats, therefore, mainly indicates biological variations within I litter.

\section{RESULTS}

\section{Ketone-body utilization by preparations from devel- oping rat brain}

Figure 1 shows that the oxidation of $\left[3-{ }^{14} \mathrm{C}\right]$ acetoacetate to ${ }^{14} \mathrm{CO}$, by rat-brain homogenates increased until day 20 , followed by a gradual decrease to an adult level which was equal to the rate found just after birth (approx $1 \mu \mathrm{mol} / \mathrm{g}$ brain $/ \mathrm{h}$ ). The oxidation of $\left[\mathrm{U}^{14} \mathrm{C}\right] \mathrm{glucose}$ was low after birth and increased to an adult rate of $0.7 \mu \mathrm{mol} / \mathrm{g}$ brain $/ \mathrm{h}$. The incorporation of $\left[3-{ }^{14} \mathrm{C}\right]$ acetoacetate into lipids by homogenates of developing rat brain was slightly higher $(60 \mathrm{nmol} / \mathrm{g} / \mathrm{h})$ for the second week than for the first week after birth and decreased during the third week and post-weaning period down to very low rates in adult rats $(<10 \mathrm{nmol} / \mathrm{g} / \mathrm{h}$; Fig. 1). D-3-Hydroxybutyrate is the main circulating ketone body in the suckling rat. The developmental pattern of incorporation of this substrate into lipids was very similar to acetoacetate, though the rate was approx $30^{\circ}$ lower (not shown). Glucose slightly $\left(\leqslant 10^{\circ}\right)$ stimulated lipogenesis from acetoacetate whereas 
NADPH had no effect under our reaction conditions (see, however, Patel and Clark, 1980), indicating that lipogenesis was not limited by the availability of reducing equivalents.

The utilization of D-3-hydroxybutyrate followed a similar developmental pattern as that of acetoacetate (Table 1). The rate of acetoacetate utilization (14-32 $\mu \mathrm{mol} / \mathrm{g} / \mathrm{h})$, however, was much higher than its oxidation to ${ }^{14} \mathrm{CO}_{2}$ (Fig. 1); most of the label accumulated in acid-soluble intermediates (not shown, cf. Lopes-Cardozo and Klein, 1982).

Optimal doses of pyruvate and acetate were compared with ketone bodies as precursors for lipid synthesis by brain homogenates of 2-week old rats (Table 2). The relative rates of incorporation into lipids (sum of saponifiables and non-saponifiables) of acetyl-groups derived from the various substrates decreased in the following order: Acetoacetate $(100 \%)$, D-3-hydroxybutyrate $(82 \%)$, pyruvate $(57 \%)$, acetate $(33 \%)$, glucose $(8 \%)$. About equal amounts of label from $\left[\mathrm{U}-{ }^{14} \mathrm{C}\right] \mathrm{glucose}$ and from $\left[3-{ }^{14} \mathrm{C}\right]$ acetoacetate were recovered in the total lipid fraction (before saponification). However, more than $90 \%$ of the label from $\left[\mathrm{U}-{ }^{14} \mathrm{C}\right]$ glucose was recovered in the glycerol-moiety of complex lipids whereas this was only $10 \%$ in case of $\left[3-{ }^{14} \mathrm{C}\right]$ acetoacetate. The high incorporation of ketone bodies into lipids was even more marked at younger ages.

Incorporation of tritium as a measure of lipid synthesis in vitro and in vivo

The rate of lipogenesis was also estimated by measuring incorporation of ${ }^{3} \mathrm{H}$ from ${ }^{3} \mathrm{H}_{2} \mathrm{O}$ (Stansbie et al., 1976, Table 3). This rate was about equal to the rate of lipogenesis from $\left[3-{ }^{14} \mathrm{C}\right]$ acetoacetate in the case of a brain homogenate, taking into account that acetoacetate yields two acetyl-groups. On the other hand, with a minced brain preparation only $60 \%$ of newly synthesized lipid carbon was derived from added acetoacetate indicating an important contribution from endogenous substrates.

A striking difference in composition was observed between the ${ }^{3} \mathrm{H}$-labeled lipids synthesized in vitro by homogenates as compared to the situation in vivo. In vitro ${ }^{3} \mathrm{H}$ was about equally partitioned between cholesterol, free fatty acids and acyl-groups of phospholipids (approx $0.03 \mu \mathrm{mol} / \mathrm{g} / \mathrm{h}$ to each category). On the other hand, in vivo almost no incorporation in free fatty acids was observed while ${ }^{3} \mathrm{H}$ in the acyl-groups of phosphatidylcholine and phosphatidylethanolamine accounted for more than $90 \%$ of the saponifiable lipid fraction (results not shown).

Figure 2 shows the ${ }^{3} \mathrm{H}$ incorporation into fatty acids and into $3-\beta$-hydroxysterols by developing rat brain in vivo as a function of age. A large variation was observed, even when pups from the same litter were used. This variation must have a biological origin because ${ }^{3} \mathrm{H}$ incorporation into the two separate brain hemispheres of the same pup varied by less than $10 \%$ (cf. Experimental Procedures). The amount of medulla spinalis per dissected brain is a possible source of variation because spinal cord and medulla were much more active in lipid synthesis than cortex areas, especially between day 10 and day 30 (unpublished results). ${ }^{3} \mathrm{H}$ incorporation into fatty acids was maximal between days 10 and 20 (about $3 \mu \mathrm{mol} / \mathrm{g} / \mathrm{h}$ ) and decreased slowly to approx $1 \mu \mathrm{mol} / \mathrm{g} / \mathrm{h}$ in adult rats. The ${ }^{3} \mathrm{H}$ incorporation into cholesterol varied only little during development (about $0.5 \mu \mathrm{mol} / \mathrm{g} / \mathrm{h}$ ) but dropped to very low rates in adult rats.

Data on the weight and on the total fatty acid cholesterol content of developing rat brain (Fig. 3) were obtained from littermates of the pups used for the measurements of ${ }^{3} \mathrm{H}$ incorporation (Fig. 2). The total amounts of fatty acids and of cholesterol increased though at a slightly slower rate than the increase in brain weight during the phase of rapid growth (day $0 \rightarrow 20$ ). After day 20 , when myelination proceeds, the rate of lipid deposition becomes higher in the brain than its gain in weight.

\section{DISCUSSION}

Ketone-body utilization in vitro: Distribution between oxidation and lipid synthesis

Only a small fraction $(<10 \%)$ of the carbon derived from ketone bodies which were utilized by brain homogenates (Table 1) was recovered in metabolic end-products $\left(\mathrm{CO}_{2}\right.$ and lipids, Fig. 1). This phenomenon was observed previously with homogenates from adult rat brain (Lopes-Cardozo and Klein, 1982) and could be explained by an extensive accumulation of labeled, acid-soluble intermediates.

The developmental patterns of ketone-body utilization (Table 1) and of the conversion of $\left[3-{ }^{13} \mathrm{C}\right.$ ]acetoacetate into ${ }^{14} \mathrm{CO}_{2}$ (Fig. 1) reflect changes in the activities of enzymes involved in ketone-body metabolism in developing rat brain. The activities of 3-hydroxybutyrate dehydrogenase (EC 1.1.1.30) and of 3-oxoacid CoA-transferase (EC 2.8.3.5) increase until the end of the third postnatal week and decrease after weaning to low values in the adult (Page $e t$ al., 1971). Our data differ from a report by Yeh et al. (1977) who observed maximal ${ }^{14} \mathrm{CO}_{2}$ production from 


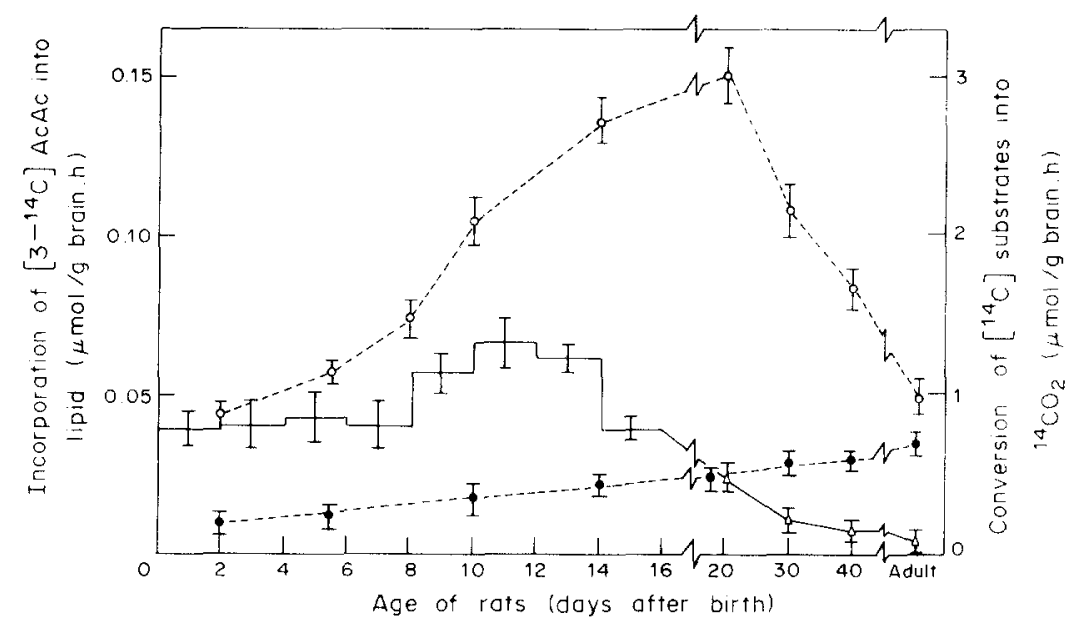

Fig. 1. Oxidation and lipid synthesis by brain homogenates of developing rats. ${ }^{14} \mathrm{C}$ Incorporation from $\left[3-{ }^{-4} \mathrm{C}\right]$ acetoacetate $(4 \mathrm{mM}, 0.1 \mathrm{Ci} / \mathrm{mol})$ into $\mathrm{CO}_{2}(\mathrm{O}-\cdots \mathrm{O})$ and into lipids $(\triangle-\triangle)$ was compared with ${ }^{14} \mathrm{CO}_{2}$ formation from $\mathrm{D}-\left[\mathrm{U}-{ }^{14} \mathrm{C}\right]$ glucose $(10 \mathrm{mM}, 0.1 \mathrm{Ci} / \mathrm{mol})\left({ }^{-}-{ }^{-}\right)$. The values for ${ }^{14} \mathrm{C}$ incorporation into lipids up to day 16 were obtained from pups of 16 separate litters (day 1 to day 16). The results were averaged over 3-day periods (day $0-2,2-4$ etc.). Bars indicate the SD.

$\left[3-{ }^{14} \mathrm{C}\right]$ acetoacetate by brain homogenates from 5 -day old rat pups.

Ketone bodies were also used for lipid synthesis by homogenates of young rat brain (Fig. 1; Table 2), in contrast to brain homogenates of adult rats (Fig. 1 and Lopes-Cardozo and Klein, 1982; see however Yeh et al., 1977). Higher rates of lipid synthesis by homogenates of developing rat brain have been re- ported by other groups (Yeh et al., 1977; Patel and Clark, 1980). We found higher rates only with minced (Table 3) or sliced (not shown) brain preparations, indicating that cellular integrity is important for the incorporation of ketone bodies into lipids. The preferential use of ketone bodies compared to glucosederived carbon for the synthesis of cholesterol (Table 2 . last column) is expressed more clearly in the brain

Table 2. The conversion of various $\left[{ }^{14} \mathrm{C}\right]$ labelled substrates to ${ }^{14} \mathrm{CO}_{2}$ and the incorporation of ${ }^{14} \mathrm{C}$ into lipids by brain homogenates from 2 -week old rats

\begin{tabular}{|c|c|c|c|}
\hline \multirow[b]{2}{*}{ Added $\left[{ }^{14} \mathrm{C}\right]$ substrate } & \multicolumn{2}{|c|}{$\begin{array}{c}\text { Conversion into }\left[{ }^{14} \mathrm{C}\right] \text { products } \\
(\mu \mathrm{mol} / \mathrm{g} \text { brain } / \mathrm{hr})\end{array}$} & \multirow{2}{*}{$\begin{array}{l}\text { Sterol } \\
\text { Falty acid }\end{array}$} \\
\hline & $\mathrm{CO}_{2}$ & Lipids & \\
\hline $\begin{array}{l}{\left[3-^{14} \mathrm{C}\right] \text { Acetoacetate }} \\
(4 \mathrm{mM}, 0.1 \mathrm{Ci} / \mathrm{mol})\end{array}$ & $2.85 \pm 0.22$ & $0.038 \pm 0.003$ & 0.82 \\
\hline $\begin{array}{l}{\left[3-{ }^{14} \mathrm{C}\right] \mathrm{D}-3-\mathrm{Hydroxybutyrate}} \\
(4 \mathrm{mM}, 0.1 \mathrm{Ci} / \mathrm{mol})\end{array}$ & $2.52 \pm 0.61$ & $0.031 \pm 0.005$ & 0.72 \\
\hline $\begin{array}{l}{\left[\mathrm{U} \cdot{ }^{14} \mathrm{C}\right] \mathrm{Glucose}} \\
(0.1 \mathrm{Ci} / \mathrm{mol})\end{array}$ & $0.42 \pm 0.04$ & $0.003 \pm 0.001$ & $\cdots+$ \\
\hline $\begin{array}{l}{\left[2-{ }^{14} \mathrm{C}\right] \text { Pyruvate }} \\
(5 \mathrm{mM}, 0.1 \mathrm{Ci} / \mathrm{mol})\end{array}$ & $3.49 \pm 0.24$ & $0.043 \pm 0.007$ & 0.56 \\
\hline $\begin{array}{l}{\left[1 .{ }^{14} \mathrm{C}\right] \text { Acetate }} \\
(5 \mathrm{mM}, 0.1 \mathrm{Ci} / \mathrm{mol})\end{array}$ & $0.88 \pm 0.13$ & $0.025 \pm 0.002$ & 0.95 \\
\hline
\end{tabular}

†Incorporation into sterols was below the detection level $(<0.001 \mu \mathrm{mol} / \mathrm{g} / \mathrm{h})$.

The incubation medium (Experimental Procedures) was supplemented with $10 \mathrm{mM}$ D-glucose and various $\left[{ }^{14} \mathrm{C}\right]$ labelled substrates indicated in the Table. The radioactivity in $\mathrm{CO}_{2}$ and in the saponifiable and non-saponifiable lipid-fractions was measured (the sum of these fractions is tabulated under Lipids). Mean $\pm \mathrm{SE}$; for acetoacetate $n=7$, for other substrates $n=3$. The last column gives the ratio of ${ }^{14} \mathrm{C}$ incorporation into the non-saponifiable lipid fraction over the saponifiable lipid fraction. 
Table 3. The incorporation of label from ${ }^{3} \mathrm{H}_{2} \mathrm{O}$ and from $\left[3-{ }^{14} \mathrm{C}\right]$ acetoacetate into the saponifiable and non-saponifiable lipid fractions by 10-day old rat brain in vitro and in vivo

\begin{tabular}{|c|c|c|c|c|}
\hline & \multicolumn{4}{|c|}{$\begin{array}{l}\text { Incorporation into lipids } \\
(\mu \mathrm{mol} / \mathrm{g} \text { brain } / \mathrm{hr})\end{array}$} \\
\hline & \multicolumn{2}{|c|}{${ }^{3} \mathrm{H}$ from ${ }^{3} \mathrm{H}_{2} \mathrm{O}$} & \multicolumn{2}{|c|}{${ }^{14} \mathrm{C}$ from $\left[3^{14} \mathrm{C}\right]$ acetoacetate } \\
\hline & $\begin{array}{l}\text { Saponifiable } \\
\text { lipids }\end{array}$ & $\begin{array}{l}\text { Non-saponifiable } \\
\text { lipids }\end{array}$ & $\begin{array}{l}\text { Saponifiable } \\
\text { lipids }\end{array}$ & $\begin{array}{l}\text { Non-saponifiable } \\
\text { lipids }\end{array}$ \\
\hline Brain homogenates & 0.05 & 0.04 & 0.03 & 0.02 \\
\hline Brain mince & 0.31 & 0.10 & 0.10 & 0.04 \\
\hline Brain in vivo & 2.5 & 0.5 & - & - \\
\hline
\end{tabular}

For in vitro experiments $18 \mathrm{mCi}{ }^{3} \mathrm{H}_{2} \mathrm{O}, 4 \mathrm{mM}\left[3-{ }^{14} \mathrm{C}\right]$ acetoacetate $(0.1 \mathrm{Ci} / \mathrm{mol})$ and $10 \mathrm{mM}$ D-glucose were added to the incubation medium.

in vivo (Webber and Edmond, 1979; Yeh, 1980; Koper et al., 1981).

Lipid synthesis by developing rat brain in vivo; comparison with in vitro results

The developmental patterns of lipid synthesis in vitro (Fig. 1) and in vivo (Fig. 2) show some striking differences. The utilization of acetoacetate for lipid synthesis by brain homogenates (Fig. 1) remained almost constant throughout the suckling period and dropped to a very low level after weaning. Lipogenesis in vivo (Fig. 2) on the other hand increased after birth until day 15 and decreased slowly afterwards to a rate in adult rats which was still about $50 \%$ of the maximal rate.

These results suggest that ketone bodies are important precursors for synthesis of brain lipids only during the suckling period in which they are indeed

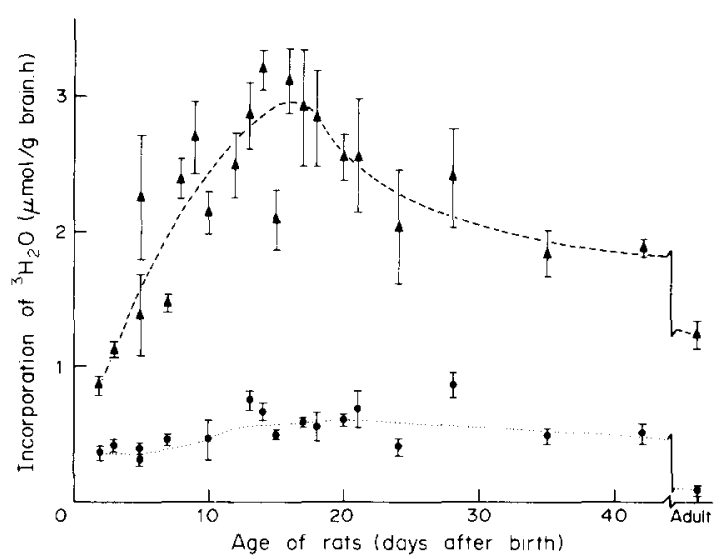

Fig. 2. Incorporation of ${ }^{3} \mathrm{H}$ from ${ }^{3} \mathrm{H}_{2} \mathrm{O}$ into total fatty acids and into $3-\beta$-hydroxysterols by developing rat brain in vivo-( $\mathbf{A}----\mathbf{A})$, incorporation into total fatty acids (saponifiable fraction) (O....), incorporation into 3- $\beta$-hydroxysterols (non-saponifiable, digitoninprecipitable). Mean \pm SD. among the physiological substrates (Robinson and Williamson, 1980).

Using the incorporation of ${ }^{3} \mathrm{H}$ from ${ }^{3} \mathrm{H}_{2} \mathrm{O}$ as an index for lipogenic rate, we found that this process is at least 8 -fold more active in vivo than in vitro (Table 3). The distribution of the ${ }^{3} \mathrm{H}$ label among lipid classes was also quite different.

Various factors could be involved in lowering the lipogenic capacity of in vitro preparations like: (1) dilution of cofactors (2) induction of a catabolic rather than anabolic state by cellular damage (3) a block in the synthesis of complex lipids. As NADPH, ATP and CoASH did not stimulate lipogenesis by homogenates, we have no evidence for (1), (2) and (3)

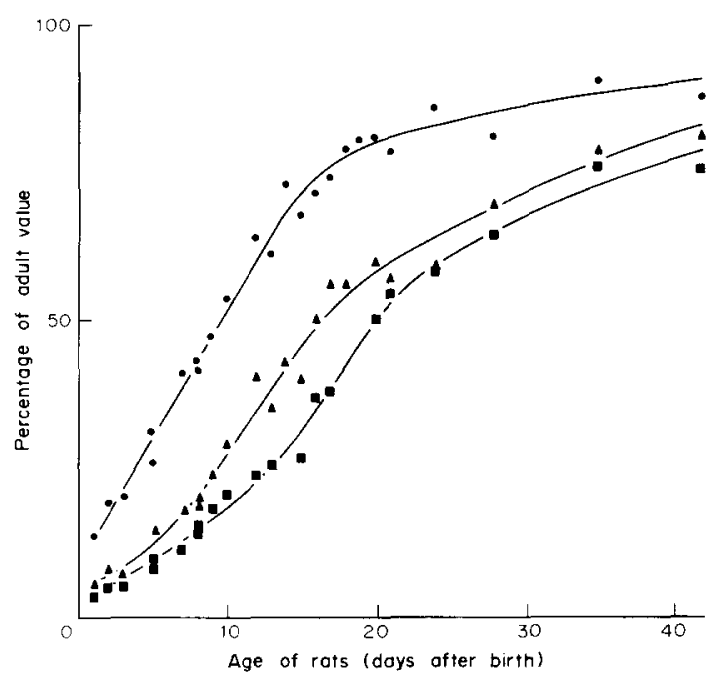

Fig. 3. Increase in wet weight and in total fatty acid and cholesterol content during development of rat brain. ( - ) brain weight. ( $\mathbf{A}-\mathbf{\Delta}$ ), total fatty acids. (口- ), cholesterol. Values from adult rats $(q, 225 \mathrm{~g}$ body weight) were: $1.54 \pm 0.03 \mathrm{~g}$ brain wet weight, $143.3 \pm 6.0 \mu \mathrm{mol}$ total fatty acids/brain, $76.4 \pm 4.5 \mu \mathrm{mol}$ cholesterol/brain. 
Table 4. Comparison of the increase in brain lipids during postnatal growth and the rate of ${ }^{3} \mathrm{H}$ incorporation from ${ }^{3} \mathrm{H}_{2} \mathrm{O}$ in these lipids

\begin{tabular}{|c|c|c|c|c|}
\hline \multirow[b]{2}{*}{ Postnatal period, day } & \multicolumn{2}{|c|}{ Cholesterol } & \multicolumn{2}{|c|}{ Fatty acids } \\
\hline & $10 \cdot 20$ & $30 \rightarrow 40$ & $10 \cdot 20$ & $30+40$ \\
\hline $\begin{array}{l}\text { Increase } \\
\text { ( } \mu \text { mol/brain) } \\
\text { (acetyl- } \mu \text { eq. } / \text { brain) }\end{array}$ & $\begin{array}{r}22 \\
396\end{array}$ & $\begin{array}{r}6 \\
108\end{array}$ & $\begin{array}{r}52 \\
416\end{array}$ & $\begin{array}{r}15 \\
120\end{array}$ \\
\hline $\begin{array}{l}\text { Incorporation of }{ }^{3} \mathrm{H}_{2} \mathrm{O} \\
(\mu \mathrm{mol} / \text { brain } / \mathrm{h})^{*} \\
(\mu \mathrm{mol} / \text { brain } / 10 \text { days })^{*}\end{array}$ & $\begin{array}{c}0.66 \\
158\end{array}$ & $\begin{array}{c}0.84 \\
202\end{array}$ & $\begin{array}{c}2.97 \\
713^{2}\end{array}$ & $\begin{array}{l}3.08 \\
739\end{array}$ \\
\hline
\end{tabular}

appear more likely because we observed an accumulation of labeled free fatty acids in vitro whereas in vivo de novo synthesized fatty acids were found predominantly in the phospholipid fraction.

\section{Contribution of endogenous synthesis to brain lipids during development}

The relatively low metabolic activity of brain preparations in vitro has led to an underestimation of the capacity of developing rat brain to synthesize fatty acids and cholesterol. An intriguing question is how this endogenous synthesis relates quantitatively to the uptake of lipids from the blood and to the over-all deposition of lipids in the brain during growth; a problem that has been discussed previously by others (Bourre, 1980; Cook, 1982; Yeh et al.. 1983). Our data shed some light on this problem: The rates of lipogenesis and cholesterogenesis can be calculated from the ${ }^{3} \mathrm{H}$ incorporation (Fig. 2) and compared with the rates of fatty acid and cholesterol deposition during development of the rat (Fig. 3). Such calculations have been carried out in Table 4 for two 10-days periods: Period I (days 10 20), when the growth rate of the brain is maximal. Period II (days $30-40$ ), after weaning when the brain weight increases at a much slower rate (Fig. 3). It should be noted that the results of Table 4 must be interpreted with caution because: (i) ${ }^{3} \mathrm{H}$ incorporation was taken from the experiment in Fig. 2 and extrapolated (and averaged) over a 10-day period. Linearity of ${ }^{3} \mathrm{H}$ incorporation over a 1-day period was observed, however (Experimental Procedures). (ii) The stoicheiometry of ${ }^{3} \mathrm{H}$ incorporation into brain lipids is not known (cf. Cenedella, 1982). Ratios of 0.9 and 0.7 of ${ }^{3} \mathrm{H}_{2} \mathrm{O}$ per acetyl-group incorporated into fatty acids (Lowenstein et al., 1975) and into sterols (Andersen and Dietschy, 1979) are generally adopted.

The following conclusions can be drawn from the results in Table 4: (a) In period I more cholesterol is deposited than synthesized in the brain, indicating an exogenous contribution. (b) In period II the situation is reversed: ${ }^{3} \mathrm{H}$ incorporation into cholesterol greatly exceeds the rate of cholesterol deposition. This may result from turnover of brain cholesterol, which is unlikely (Dhopeshwarkar and Subramanian, 1981), or from export of cholesterol from the brain. (c)

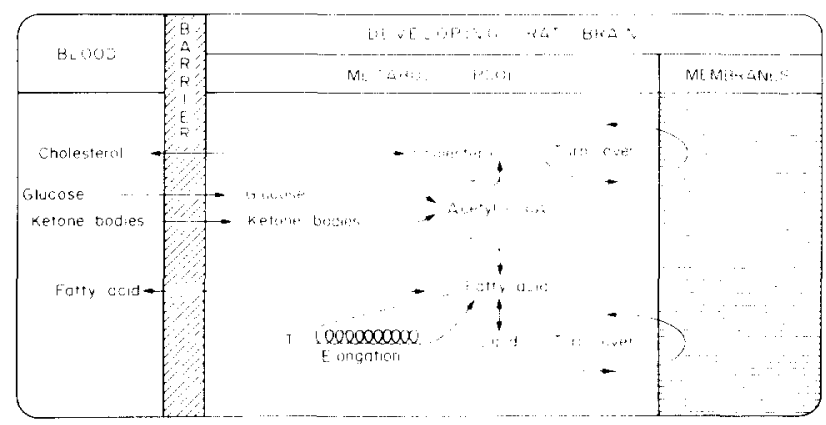

Fig. 4. Scheme of fatty acid and cholesterol metabolism in developing rat brain. T, entry of ${ }^{3} \mathrm{H}$ from ${ }^{3} \mathrm{H}_{2} \mathrm{O}$. 
Incorporation of ${ }^{3} \mathrm{H}$ into fatty acids greatly exceeds the deposition of fatty acids in developing brain in period I and even more so in period II. This discrepancy between ${ }^{3} \mathrm{H}$ incorporation and deposition of fatty acid is even more pronounced in view of the high content of polyunsaturated fatty acids in brain (approx 30\%) (Bourre, 1980) which require linoleic and linolenic acids as precursors (Sinclair, 1975). Figure 4 tries to fit these conclusions into a conceptual framework. Cholesterol and fatty acids can be synthesized de novo by developing rat brain or can be imported from the blood. Part of the fatty acids are processed (elongation, desaturation) before their incorporation into complex lipids. The contribution of ketone bodies as lipid precursors is difficult to quantify in vivo (cf. Koper et al., 1981). Recent data indicate, however, that ketone bodies contribute 33 and $50 \%$ to the synthesis of fatty acids and cholesterol, respectively, in the brains of 18-day old rats (Bergstrom et al., 1981).

Our ${ }^{3} \mathrm{H}$-incorporation data indicate that turnover and/or export of cholesterol and fatty acids are quantitatively important processes during brain development. Even in adult rats ${ }^{3} \mathrm{H}$ is incorporated into brain fatty acids at a rate of about $1 \mu \mathrm{mol}$ ${ }^{3} \mathrm{H}_{2} \mathrm{O} / \mathrm{g} / \mathrm{h}$ (Fig. 2) which is equivalent to $40 \mu \mathrm{mol}$ acetyl-groups (about $2 \%$ of its total fatty acid content) per brain per day.

Acknowledgements-This investigation was supported in part by the Netherlands Foundation for Chemical Research (SON) with financial aid from the Netherlands Organization for the Advancement of Pure Research (ZWO). We thank Professor S. G. van den Bergh for his critical reading of the manuscript.

\section{REFERENCES}

Andersen J. M. and Dietschy J. M. (1979) Absolute rates of cholesterol synthesis in extrahepatic tissues measured with ${ }^{3} \mathrm{H}$-labeled water and ${ }^{14} \mathrm{C}$-labeled substrates. J. Lipid Res. 20, 740-752.

Bergstrom J. D., Sonnenberg N., Webber R. J. and Edmond J. (1981) Rates of lipogenesis in infant rat brain; estimates of contributions by blood metabolites. Abstracts of the $8 \mathrm{th}$ Meeting of the International Society for Neurochemistry, Nottingham, U.K., p. 58.

Bligh E. G. and Dyer W. J. (1959) A rapid method of total lipid extraction and purification. Can. J. Biochem. Physiol. 37, 911-917.

Bourre J.-M., Paturneau-Jouas M. Y., Daudu O. L. and Baumann N. A. (1977) Lignoceric acid biosynthesis in the developing brain. Activities of mitochondrial acetyl-CoA dependent synthesis and microsomal malonyl-CoA chainelongating system in relation to myelination. Eur. $J$. Biochem. 72, 41-47.

Bourre J.-M. (1980) Origin of aliphatic chains in the brain. In: Neurological Mutations Affecting Myelination. IN-
SERM Symposium No. 14 (Baumann N., ed.), pp. 187-206. Elsevier/North-Holland, Amsterdam.

Cenedella R. J. (1982) Sterol synthesis by the ocular lens of the rat during postnatal development. J. Lipid Res. 23, 619-626.

Cook H. W. (1978) In vitro formation of polyunsaturated fatty acids by desaturation in rat brain: Some properties of the enzymes in developing brain and comparisons with liver. J. Neurochem. 30, 1327-1334.

Cook H. W. (1982) Chain elongation in the formation of polyunsaturated fatty acids by brain: Some properties of the microsomal system. Archs Biochem. Biophys. 214, 695-704.

Dhopeshwarkar G. A. and Mead J. F. (1973) Uptake and transport of fatty acids into the brain and the role of the blood-brain barrier system. Adv. Lipid Res. 11, 109-142.

Dhopeshwarkar G. A. and Subramanian C. (1977) Lipogenesis in the developing brain from intracranially administered []$\left.^{14} \mathrm{C}\right]$ acetate and $\left[\mathrm{U}^{14} \mathrm{C}\right]$ glucose. Lipids 12, $762-764$.

Dhopeshwarkar G. A. and Subramanian C. (1981) Lack of catabolism of brain cholesterol. Lipids 16, 389-392.

Jeske D. J. and Dietschy J. M. (1980) Regulation of rates of cholesterol synthesis in vivo in the liver and carcass of the rat measured using $\left[{ }^{3} \mathrm{H}\right]$ water. J. Lipid Res. 21, $364-376$.

Koper J. W., Lopes-Cardozo M. and Van Golde L. M. G. (1981) Preferential utilization of ketone bodies for the synthesis of myelin cholesterol in vivo. Biochim. biophys. Acta 666, 411-417.

Lopes-Cardozo M., Klein W. and Jager J. E. (1980) Utilisation of ketone bodies by rat brain homogenates. In: Synaptic Constituents in Health and Disease (Brzin M. Sket D. and Bachelard H., eds), p. 622. Eur. Soc. Neurochem. Meeting. Mlodinska Knjiga, Pergamon Press, Oxford.

Lopes-Cardozo M. and Klein W. (1982) Ketone-body utilization by homogenates of adult rat brain. Neurochem. Res. 7, 687-703.

Lowenstein J. M., Brunengraber H. and Wadke M. (1975) Measurement of rates of lipogenesis with deuterated and tritiated water. Meth. Enzym. 35B, 279-287.

Lyles D. S., Sulya L. L. and White H. B. (1975) The effect of essential fatty acid deficiency upon fatty acid uptake by the brain. Biochim. biophys. Acta 388, 331-338.

Metz S. H. M., Mulder I. and Van den Bergh S. G. (1973) Regulation of lipolysis in bovine adipose tissue by the degree of plasma albumin with fatty acids. Biochim. biophys. Acta 306, 42-50.

Murad S. and Kishimoto Y. (1978) Chain elongation of fatty acid in brain: A comparison of mitochondrial and microsomal enzyme activities. Archs Biochem. Biophys. 185, 300-306.

Page M. A., Krebs H. A. and Williamson D. H. (1971) Activities of enzymes of ketone-body utilization in brain and other tissues of suckling rats. Biochem. J. 121, 4953.

Pande S. V. (1976) Liquid scintillation counting of aqueous samples using Triton-containing scintillants. Analyt. Biochem. 74, 25-34.

Patel M. S. and Owen O. E. (1977) Development and regulation of lipid synthesis from ketone bodies by rat brain. J. Neurochem. 28, 109-114.

Patel T. B. and Clark J. B. (1980) Lipogenesis in the brain of suckling rats-Studies on the mechanism of 
mitochondrial-cytosolic carbon transfer. Biochem. J. 188, $163-168$

Robinson A. M. and Williamson D. H. (1980) Physiological roles of ketone bodies as substrates and signals in mammalian tissues. Physiol. Rer. 60, 143-187.

Sinclair A. J. (1975) Incorporation of radioactive poly. unsaturated fatty acids into liver and brain of developing rat. Lipids 10, 175-184.

Stansbie D., Brownsey R. W. Crettaz M. and Denton R. M. (1976) Acute effects in tivo of anti-insulin serum on rates of fatty acid synthesis and activities of acetylcoenzyme A carboxylase and pyruvate-dehydrogenase in liver and epididymal adipose tissue of fed rats. Biochem. J. 160, 413-416.

Webber R. J. and Edmond J. (1979) The in tive utilization of acetoacetate. D- $(-)$-3-hydroxybutyrate and glucose for the lipid synthesis in brain in the 18-day-old rat; evidence for an acetyl-CoA bypass for sterol synthesis. $J$. hiol. (hem. 254, 3912-3920.

Williamson D. H. Mellanby J. and Krebs H. A. (1962) Enzymic determination of $D(-\cdots)-\beta$-hydroxybutyric acid and acetoacetic acid in blood. Biochem. J. 82, 90-96.

Yeh Y.-Y.. Streuli V. L. and Zee P. (1977) Ketone bodies serve as important precursors of brain lipids in the developing rat. Lipids 12, 957.964.

Yeh Y.-Y. (1980) Partition of ketone bodies into cholesterol and fatty acids in rivo in different brain regions of developing rats. Lipids $15,904907$.

Yeh Y.-Y.. Ginsburg J. R. and Tso T. B. (1983) Changes in lipogenic capacity and activities of ketolytic and lipogenic enzymes in brain regions of developing rats. J. Neurochem. 40, 99 - 105.

Zlatkis A. and Zak B. (1969) Study of a new cholesterol reagent. Analyt. Biochem. 29, 143-148. 